\title{
RESEPSI JAMAAH MAJELIS TAKLIM AT-TAQWA TERHADAP HADIS-HADIS MUSHKIL DAN IMPLIKASINYA DALAM KEPEDULIAN KEPADA SESAMA DENGAN PENDEKATAN PSIKOLOGI ORGANISASI
}

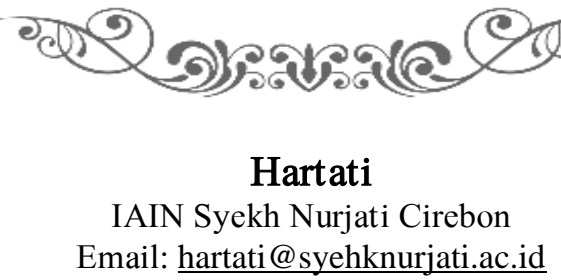

\begin{abstract}
This article discusses the reception of At-Taqwa Majlis Taklim to the mushkil of hadiths and their implications for social care. The mushkil of hadiths are widely used as study material for woman recitation groups, even though the hadiths are usually used as objects of studies by researchers or scholars of hadiths. From the understanding of At-Taqwa Taklim Majlis, the mushkil hadiths related to the theme of Aqidah initiated the charity and donation programs of this majlis. This article aimed to find out the reception of At-Taqwa Taklim Majlis' jama'ah to the four themes of mushkil hadiths, to elaborate the ulama's explanation, and to examine the relationship of mushkil hadiths with social care. The methods used in this study were field research and library research with an approach of organizational psychology. The results show that the understanding of At-Taqwa Majlis Taklim jama'ah on mushkil hadiths was formed through organizational psychology with the indicators of leadership, job satisfaction, employees/members' motivation, organizational change, and group processes in an organization.
\end{abstract}

Keywords: mushkil hadith, reception of hadith, social care, organizational psychology 


\begin{abstract}
Abstrak
Artikel ini membahas resepsi majelis taklim at-Taqwa terhadap hadis Mushkil dan implikasinya terhadap kepedulian kepada sesama. Hadis Mushkil marak dijadikan sebagai bahan kajian pada pengajian ibu-ibu walaupun biasanya hadis tersebut biasa dijadikan objek studi para akademisi di bidang Hadis. Dari pemahaman majelis taklim at-Taqwa Hadis Mushkilyang terkait tema Aqidah, menginisiasi munculnya program santunan dan donasi pada majelis ini. Artikel ini bertujuan untuk mengetahui resepsi jemaah Majelis Taklim at-Taqwa terhadap keempat tema Hadis Mushkil, memaparkan penjelasan ulama dan menelaah keterkaitan hadis Mushkil dengan sikap peduli terhadap sesama. Metode kajian yang dipakai dalam tulisan ini adalah field research dan library research dengan pendekatan psikologi organisasi. Hasilnya menunjukan pemahaman jamaah Majelis Taklim at-Taqwa terhadap hadis Mushkil terbentuk melalui psikologi organisasi indicator kepemimpinan. kepuasan kerja, motivasi karyawan/anggota, perubahan organisasi dan proses grup dalam suatu organisasi.

Kata Kunci: Hadis Mushkil, resepsi Hadis, kepedulian sosial dan
\end{abstract} psikologi organisasi.

\title{
PENDAHULUAN
}

Resepsi (penerimaan) setiap orang akan berbeda terhadap sesuatu yang dibaca dan didengar. Tentunya penerimaan tersebut sesuai dengan suasana diri yang menerima pesan, pemikiran, pengalaman, keilmuan dan lingkungan. Hadis Mushkil adalah hadis yang masih samar dan sulit dipahami, sehingga memerlukan pembuktian dengan kajian lebih lanjut. Berbeda dengan Hadis Muhkam yang langsung bisa dipahami isinya. Memahami Hadis Mushkil dapat berimplikasi baik terhadap akidah, kesadaran spiritual, dan kesadaran sosial.

Wilayah kajian hadis tentu berkutat pada ranah teks dan kontek. Teks hadis pada zaman Nabi saw ditulis pada kulit kayu, tulang unta, batu dan kertas (masih sedikit jumlahnya). ${ }^{1}$ Pada masa itu, sahabat yang tidak mengerti terhadap maksud Hadis, dapat langsung bertanya kepada Nabi saw. dari sini timbul anggapan bahwa Hadis Rasulullah Saw ada yang mudah dipahami dan tidak. Sama halnya dengan ayat Alquran ada yang muhkamāt dan mutashābihāt. Hadis yang sukar dipahami itulah kemudian disebut sebagai Hadis Mushkil. Sehingga dalam memhami hadis tersbut terlebih dahulu harus

${ }^{1}$ M.M. A'zami, Hadis Nabi dan Sejarah Kodifikasinya (Jakarta: Pustaka Firdaus, 
melihat konteks asbāb al-wurūd, konteks budaya, linguistik dan lain sebagainya. Indikator-indikator itu dapat menjawab ke-mushkil-an suatu hadis. Hal ini pernah juga dilakukan oleh Imām Shāfi'’ $(150-204 \mathrm{H})^{2}$, dan Muhammad ibn Qutaybah (213-276 H) ${ }^{3}$ yang mengkaji hadis Nabi Saw. dengan penjelasan secara mendalam.

Berangkat dari permasalahan itu, dalam tulisan ini selain menggunakan pendekatan ilmu hadis, juga akan menggunakan pendekatan psikologi organisasi juga. Psikologi digunakan agar lebih fokus dalam menjelaskan tingkah laku manusia, baik yang terkait perkembangan psikis manusia, aktivitas manusia terkait masalah sosial, penyesuaian diri dengan lingkungan, perilaku manusia dan fungsi organ tubuhnya, dan sebagainya. Sedangkan psikologi organisasi digunakan agar lebih fokus meneliti tingkah laku dan hubungan para anggotanya terutama dalam dunia kerja dan organisasi. ${ }^{4}$ Psikologi organisasi termasuk dalam kategori psikologi terapan. Karena adanya interaksi beberapa orang secara intensif dan adanya tujuan personal dan kolektif.

Psikologi organisasi sering kali disatukan pembahasannya dengan psikologi industri, karena memiliki kesamaan wilayah kajiannya, yaitu sebuah lembaga yang mempunyai struktur organisasi di dalamnya. Adapun wilayah kajiannya tidak terlepas dari issues of leadearship, job satisfaction, emfloyee motivation, organizational communication, conflict management, organizational change, and grouf prosses within an organization. Awalnya psikologi industri hanya menerapkan aspek psikologis pada dunia industri, tetapi semakin zaman berkembang dan maju maka namanya berubah menjadi psikologi industri dan organisasi. ${ }^{5}$

\section{PEMBAHASAN}

\section{Sekilas tentang Hadis Mushkil}

Abdul Mustaqim mendefinisakan hadis Mushkil sebagai hadis yang redaksinya sulit dipahami, baik karena gharīb (asing) teksnya ataupun karena isi hadis bertentangan (mukhtalif) dengan logika dan ilmu pengetahuan. ${ }^{6}$ Dalam memahami hadis Mushkil dibutuhkan pendekat an multidisipliner yang tidak hanya berorintasi pada kajian teks semata, tapi harus memperhatikan terhadap konteks hadis tersebut. Hal ini perlu dilakukan karena bisa jadi saat hadis itu muncul, pemahaman manusia belum menjangkaunya. Berbeda

${ }^{2}$ Imam Syafi' i, Ikhtilaf al-Hadith (Beirut: Dār Kutub al-'Ilmiyah, t.th)

${ }^{3}$ Ibnu Qutaybah, Ta’wīl Mukhtalif al-Hadith (Beirut: Dār al-Fikr, 1995)

${ }^{4}$ Khanza Savitra, "Psikologi Industri dan Organisasi: Perkembangan, Teori, Peran dan Penjelasannya." https://dosenpsikologi.com, diunduh 22 Juni 2020.

5 Made Diah Lestari dkk, "Psikologi Industri dan Organisasi," https://simdos.unud.ac.id, diunduh 22 Juni 2020.

${ }^{6}$ Abdul Mustaqim, Ilmu Ma'anil Hadis Paradigma Interkoneksi (Yogyakarta: Idea Press, 2016), 82 
dengan kondisi sekarang di mana sains sudah sangat maju, maka cara memahami hadis dengan penelitian sains akan dapat mengungkap maksud dari hadis tersebut. ${ }^{7}$

Jumlah hadis yang tergolong Mushkil baik secara rasio maupun yang memerlukan pembuktian sains tidak dapat ditentukan. Hadis-hadis tersebut terdapat pada Kutub al-Sittah (sahịh al-Bukhärī, sahịh Muslim, sunan Abü Dāwud, sunan al-Tirmidhì, sunan Nasā'i, sunan Ibn Mājah) dan kutub altis'ah (yang enam tersebut ditambah tiga yaitu sunan al-Därimī, muwatta Mālik dan musnad Aḥmad bin Hanbal). Hadis yang sulit dimengerti maksud isinya secara logika atau penelitian sains di antaranya yaitu: pertama, hadis yan terkait dengan akidah, seperti hadis mengenai matahari bersujud di malam hari, orang yang mengucapkan kalimat tauhid "là ilāha illā Allāh"pasti masuk syurga walaupun berzina dan mencuri, siksa kubur, demam sebagai serpihan api neraka jahanam, Allah Swt mengambil kesaksian manusia di alam arwăh, manusia tidak akan hidup pada tahun ke-100, matahari dan bulan akan masuk neraka dan lain sebagainya. Kedua, hadis yang berkenaan dengan makanan dan minuman, seperti hadis tentang lalat yang hinggap di makanan atau minuman, memakan kurma dapat menahan lapar merasa lapar, air zam-zam, makan dan minum dengan berdiri, dan lain sebagainya. Ketiga, hadis yang termasuk pada tema pengobatan, seperti hadis tentang habbat al-sawdā' bisa menyembuhkan segala macam penyakit, teknik pengobatan dengan memakai besi yang dihangatkan dan mantra, dan lain sebagainya. Keempat, hadis yang membahas perihal politik, misalnya hadis tentang kepemimpinan dari suku Quraish, larangan perempuan menjadi pemimpin, dan lain sebagainya. ${ }^{8}$

\section{Teori Kepedulian Sosial}

Kepedulian sosial dapat diartikan sebagai suatu sikap perhatian terhadap urusan orang lain yang termasuk anggota kelurga, organisasi, atau masyarakat, tetapi bukan bertujuan untuk mencampuri urusan orang lain. Fokus dari kepedulian sosial ini adalah untuk membantu menyelesaikan permasalahan yang dihadapi orang lain dengan maksud berbuat kebaikan dan menjalin perdamaian. ${ }^{9}$

Kepedulian sosial terbagi ke dalam beberapa aspek, di antaranya: pertama, kepedulian sosial kepada Tuhan. Manusia sebagai makhluk sosial yang tidak bisa hidup sendiri memiliki karakteristik eksistensi sebagai manusia yang harus dicari dalam relasi dengan Sang Pencipta. Manusia

${ }^{7}$ Nizar Ali, Hadis Versus Sains Memahami Hadis-hadis Musykil (Yogyakarta: Teras, 2008), 10

${ }^{8}$ Ibn Qutaibah, Rasionalitas Nabi saw (Jakarta: alGhuraba,2008),v-viii

${ }^{9}$ A. Shalaby, Kehidupan Sosial Dalam Pemikiran Islam (Bandung: Amzah, 2001), 
membutuhkan hubungan interaksi terhadap Tuhan sebagai manifestasi meminta segala macam keperluannya. ${ }^{10}$ Salah satu cara yang dilakukan untuk menjaga relasi tersebut dengan melakukan Ibadah. Hal ini mempunyai peranan penting sebagai landasan yang kuat dan sebagai wujud dari pengakuannya sebagai makhluk yang diciptakan oleh Sang Khalik. Ibadah, khususnya salat disebut sebagai bentuk komunikasi yang kuat karena menyatukan antara manusia dengan Tuhan-nya, secaran filosofis, Allah yang memiliki kedudukan sangat tinggi rela untuk berinteraksi dengan manusia yang berada di Bumi. ${ }^{11}$

Kedua, kepedulian sosial kepada sesama manusia. Bentuk kepedulian sosial kepada manusia dalam hadis dimunculkan dengan bahasa zakat, infak dan sedekah serta perintah ihsān (berbuat baik) untuk peduli kepada sesama.

Ketiga, Kepedulian sosial terhadap hewan. Banyak hadis yang menyebutkan secara eksplisit nama-nama hewan dalam permasalahan ibadah sosial. Seperti hadis tentang Aqiqah yang secara jelas disebutkan jenis hewan yang harus disembelih. Kemudian Qurban juga menyebutkan nama-nama hewan baik kambing, sapi, kerbau, atau unta. Hewan-hewan tersebut harus disembelih dengan cara iḥsān, menggunakan alat yang tajam supaya tidak menyiksa dan menyakiti, berdoa terlebih dahulu agar binatang yang disembelih dapat memberikan manfaat terhadap sesama, dan lain sebagainya.

Keempat, kepedulian sosial kepada tumbuhan. Ajaran Islam memerintahkan kepada manusia untuk bersikap peduli pada lingkungan dan tumbuh-tumbuhan, karena tumbuhan dapat dimanfaatkan manusia untuk bahan obat-obatan, keuntungan ekonomi, dan kebutuhan pangan, sandang, dan papan. Selain itu tumbuhan juga memiliki beberapa fungsi, seperti fungsi klimatologi untuk mengat ur cuaca dan iklim, fungsi hidrologi dalam mengatur tata air, fungsi ekologi dalam mengatur siklus biogeokimia dalam menciptakan alur energy, alur $\mathrm{O}_{2}, \mathrm{CO}_{2}$ sebagai paru-paru lingkungan, serta menjadi pelindung lingkungan hidup dari berbagai pencemaran, erosi, kekeringan dan banjir. ${ }^{12}$

\section{Teori Psikologi Organisasi}

Psikologi organisasi selalu disandingkan dengan psikologi industri sehingga menyatu dengan istilah psikologi industri dan organisasi. Psikologi industri bermakna ilmu yang mempelajari perilaku manusia di tempat kerja, sedangkan psikologi organisasi adalah ilmu yang mengkaji perilaku manusia

${ }^{10}$ Bustaman Hana Djumhana, Integrasi Psikologi dalam Islam: Menuju Psikologi Islami (Yogyakarta: Pustaka Pelajar, 1997),54

${ }^{11}$ Hilmi al-Khuli, Menyingkap Rahasia Gerakan-Gerakan Sholat (Yogjakarta: Diva Press, 2012), 27.

12 Nursid Sumaatmaja, Manusia Dalam Konteks Sosial, Budaya dan Lingkungan Hidup, (Bandung: Alfabeta, 2003), 88. 
di organisasi. ${ }^{13}$ Talcott Parsons berpendapat sebagaimana yang dikutip Amitai Etzioni bahwa organisasi itu sendiri merupakan pengelompokan manusia yang sengaja dibentuk dan dikelola kembali dengan penuh pertimbangan dalam rangka mencapai beberapa tujuan tertentu. ${ }^{14}$ Hal ini ditandai dengan adanya pembagian tugas dan pengawasan.

Subjek psikologi organisasi meliputi orang-orang yang terdapat dalam organisasi itu sendiri mulai dari pemimpin, karyawan dan anggota sedangkan objeknya adalah berupa karya, produk, barang hasil dari sebuah organisasi. Adapun cakupan psikologi organisasi di antaranya: pertama, masalah kepemimpinan (issues of leadearship). Kepemimpinan merupakan kemampuan untuk mempengaruhi suatu kelompok dalam mencapai suatu tujuan. Kemampuan kemimpinan itu menurut Marshall Sashkin dan Molly Sashkin yang mengutip pendapat Kouzes dan Bennis yang menyatakan terdapat beberapa ciri yang melekat di dalamnya, yaitu kemampuan mencari peluang, visioner, mampu menjalin kolaborasi yang baik, mampu menjadi suri tauladan, dan mampu menerima kritik atas kinerjanya. ${ }^{15}$ David Sears mengungkapkan bahwa seorang leader harus memiliki ciri dasar yaitu memiliki pengaruh paling besar terhadap sikap dan keyakinan anggotanya. ${ }^{16}$ Wirawan mengungkapkan bentuk kepemimpinan yag ideal adalah adanya transformasional pemikiran antara pimpinan dan anggotanya, karismatik (muncul bila ada krisis sosial), melayani, memudahkan urusan birokrasi, memiliki spiritualitas tinggi, memiliki gaya kepemimpinan yang autentik, dan terakhir adalah mampu menjadi diri sendiri. ${ }^{17}$

Kedua, kepuasan kerja (job satisfaction). Menurut Glinow dan Mc Shan sebagaimana yang dikutp Wirawan, kepuasan kerja diartikan sebagai evaluasi pegawai tentang pekerjaannya dan kondisi pekerjaannya, penilaian tentang persepsi kharakteristik pekerjaan, lingkungannya dan pengalaman emosional di tempat kerja, dan sikap pegawai tentang macam-macam aspek dan kondisi dari pekerjaan. ${ }^{18}$

Ketiga, motivasi karyawan (emfloyee motivation). Motivatsiya atau dorongan merupakan kekuatan energi yang mengaktifkan perilaku dan menetapkan tujuan serta arahan perilaku tersebut. Ada kebutuhan dasar yang memotivasi seseorang untuk melakukan sesuatu di antaranya: (1) ingin sukses

13 Mustadin Tagala, Psikologi Industri dan Organisasi (Depok: RajaGrafindo Persada, 2018), 266.

${ }^{14}$ Amitai Etzioni, Organisasi-organisasi Modern (Depok: UI Press, 1985), 3

${ }_{15}$ Marshall Sashkin dan Molly Sashkin, Prinsip-prinsip Kepemimpinan (Jakarta: Penerbit Erlangga, 2011), 42.

16 Jonathan David Sears dan Anne Peplau, Psikologi Sosial (Jakarta: Penerbit Erlangga, t.th), 120.

${ }^{17}$ Wirawan, Kepemimpinan (Jakarta: RajaGrafindo Persada, 2013), 138-267

${ }^{18}$ Wirawan, Kepemimpinan, 698. 
baik dalam karir dan reputasi, (2) ingin berafiliasi dengan sesama baik pertemanan maupun perjodohan dan (3) ingin berkuasa supaya bisa mengatur orang lain. ${ }^{19}$

Keempat, komunikasi organisasi (organizational communication). Komunikasi diartikan sebagai suatu proses penciptaan makna antara dua orang atau lebih melalui beberapa tanda. ${ }^{20}$ Manfaat diterapkannya komunikasi jenis ini menurut Dominick seperti yang dikutip Elvinaro Ardianto di antaranya adalah sebagai pengawasan, penafsiran, keterkaitan, dan penyebaran nilai. ${ }^{21}$

Kelima, menejemen konflik (conflict management). Konflik diartikan sebagai suatu pertentangan yang terjadi antara apa yang diharapkan seseorang terhadap dirinya, orang lain, organisasi dengan realita yang terjadi. ${ }^{22}$ Masalah ini dapat terjadi antara pribadi yang satu sama lain karena faktor ketidak sukaan sehingga memunculkan benturan, baik perorangan, keluarga maupun organisasi. Menurut Cotae dan Montemayor sebagaimana yang dikutip oleh Ekawarna baha gesekan sosial bisa lahir karena beberapa faktor, seperti kecerdasan emosional, tipe kepribadian, kekurangan ketrampilan, dan defisit perhatian. ${ }^{23}$

Keenam, perubahan organisasi (organizational change). Suatu organisasi akan terus mengalami perubahan seiring dengan perkembangan kemajuan. Perubahan dapat dimungkinkan dari mulai sistem dan struktur organisasi, aplikasi ketrampilan tenaga kerja serta peningkatan pengembangan pengetahuan anggota dan lainnya. Setiap ada perubahan yang datang dari luar organisasi, maka akan mengakibatkan perubahan pada organisasi itu sendiri. ${ }^{24}$ Perubahan atau kemandegan suatu munzzamah tentu bergantung juga pada komitmen orang-orang yang ada di dalamnya. Komitmen organisasi menciptakan adanya perasaan keterikatan psikologis dan fisik pegawai kepada organisasi tempat ia bekerja atau organisasi di mana ia menjadi anggotanya. Keterikatan itu kemudian memunculkan norma, nilai dan peraturan munzzamah. Mereka yang berada dalam organisasi akan mengidentifikasikan dirinya dengan lembaga dan menginternalisasikan norma. Orang yang menjadi anggota organization akan komitmen mematuhi peraturan, kode etik dan standar kerja organisasi. ${ }^{25}$

${ }^{19}$ Mustadin Tagala, Psikologi Industri dan Organisasi, 228-230.

${ }^{20}$ Deddy Mulyana, Nuansa-nuansa Komunikasi (Bandung: Rosda Karya, 2005), 49.

${ }^{21}$ Elvinaro Ardianto dan Karlinah, Siti. Komunikasi Massa (Bandung: Sembiosa Rekatama Media, 2012), 89

${ }^{22}$ Anwar Prabu, Perilaku dan Budaya Organisasi. Perilaku dan Budaya Organisasi (Bandung: Refika Aditama, 2010), 21.

${ }^{23}$ Ekawarna, Manajemen Konplik dan Stress (Jakarta: Bumi Aksara, 2018), 25-43.

${ }^{24}$ Mustadin Tagala, Psikologi Industri dan Organisasi, 245.

${ }^{25}$ Wirawan, Kepemimpinan, 713. 
Ketujuh, proses grouf dalam suatu organisasi (grouf prosses within an organization). Setiap organisasi memiliki landasan dan tujuan masingmasing, tergantung dari jenisnya. Andi Kirana sebagaiman dikutip Anwar Prabu mengatakan bahwa seorang pemimpin sepatutnya mempunyai visi jangka panjang untuk mengantarkan organisasinya menuju tahap kemajuan sesuai perubahan zaman dan dinamika lingkungannya. Berbeda dengan Hammel dan Prahaland sebagaimana dikutip oleh Anwar Prabu yang menyatakan bahwa dengan visi saja sebenarnya tidak menjamin suatu organisasi akan maju, tetapi hal yang perlu ditekankan adalah aksi melakukan visi organisasi itu sendiri. ${ }^{26}$

\section{Sekilas Majelis Taklim at-Taqwa}

Terbentuknya Majelis Taklim at-Taqwa diawali dengan kegiatan pengajian kamis sore ba'da asar yang berlangsung sejak tahun 1993. Kajian tersbut menjadi cikal bakal lahirnya majelis taklim di masjid At-Taqwa yang ketika itu bernama masjid Raya at-Taqwa. Pengajian tersbut dikelola oleh beberapa tokoh perempuan di Cirebon, seperti $\mathrm{Hj}$. Rodiah Uzer (Isteri ketua MUI kota Cirebon), Hj. Idah Saidah Tauhid (Isteri mantan ketua STAIN Cirebon). Pengajian ketika itu baru dihadiri lima sampai sepuluh orang ibuibu saja. Aktivitas mereka di masjid hanya untuk memakmurkan rumah Allah. Kegiat annya pun baru berkisar pengajian, belum pada program-program kerja yang lain. ${ }^{27}$

\section{Pemahaman Jemaah Majelis Taklim at-Taqwa terhadap Hadis Mushkil Perspektif Psikologi Organisasi}

1. Hadis Mushkil yang Bertema Akidah

Hadis yang akan dijelaskan mengenai Matahari bersujud pada malam hari di bawah arsh. Hadisnya disandarkan kepada Abū Dhar diriwayatkan oleh Bukhārī, teksnya berbunyi:

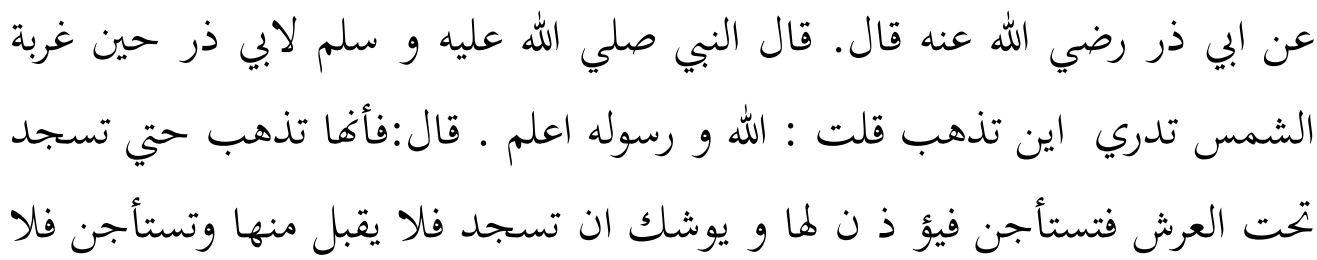

${ }^{26}$ Anwar Prabu, Perilaku dan Budaya Organisasi. Perilaku dan Budaya Organisasi, 115.

${ }^{27}$ Profil MT. at-Taqwa, 2019. 


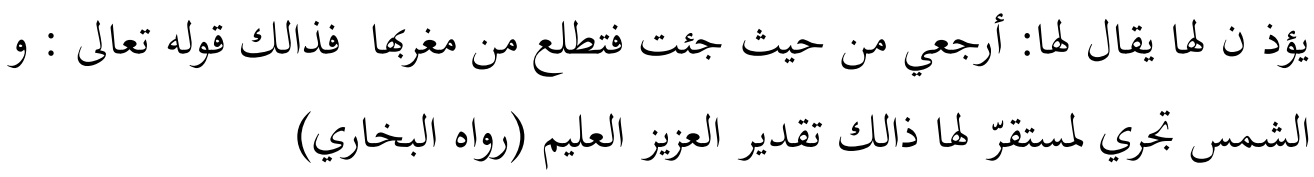

"Dari Abi Dzar, dari rasulullah saw bersabda ketika matahari terbenam: tahukah kamu kemana Matahari pergi? Aku (Abi Dzar) menjawab: Allah dan rasulnya lebih mengetahui. Beliau bersabda: Sesungguhnya dia pergi sehingga sujud di bawah Arsy. Ia meminta izin (untuk bersujud) dan izinnya diperkenankan. Lalu ia segera akan bersujud lagi, namun sujudnya tidak diterima. Ia meminta izin namun tidak diperkenankan. Maka dikatakan kepadanya: kembalilah lagi dari mana kamu datang. Maka Matahari pun muncul lagi di tempat tenggelamnya. Inilah yang difirmankan Allah dalam al-Quran: matahari berjalan di tempat peredarannya. Demikianlah ketetapan yang Maha Perkasa lagi Maha Mengetahui." 28

Jemaah majelis taklim at-Taqwa memahami hadis tersebut sesuai redaksi teks hadis seperti yang dijelaskan Ibn Hajar yang memaparkan bahwa hal ini merupakan takdir Allah swt. Hanya saja mereka belum mengetahui bahwa pensyarah kitab șahị al-Bukhari menambahkan bahwa matahari beredar di tempat yang telah ditetapkan baginya, tempat itu berada di bawah Arsh. Ibnu Hajar berpendapat bahwa kalimat "bersemayam" adalah berhenti, maksudnya setiap hari baik siang maupun malam matahari itu selalu bersujud kepada Allah. ${ }^{29}$

Walaupun jemaah majelis taklim at-Taqwa memahami hadis tersebut secara tekstual, tetapi dalam kehidupan sehari-hari mereka dapat mengimplementasikan kepedulian sosial kepada sesama. Mereka memahami bahwa matahari saja yang tidak dibekali akal pikiran dapat patuh kepada Tuhan, apalagi manusia yang diberikan Allah akal. Oleh karena itu, sebagai bentuk ketaatan mereka pada ranah sosial adalah dengan berzakat dan bersedekah. ${ }^{30}$ Ketaatan itu lahir bukan hanya dari aspek spiritual semata, tetapi bisa lahir dari nuansa psikologi organisasi yang dibangun dalam organisasi tersebut. Sebagaimana pembahasan sebelumnya bahwa seorang pemimpin dapat melakukan tindakan untuk memberikan pengaruh persepsi, dan motivasi terhadap anggotanya sehingga mereka merasa puas terhadap tindakan pemimpinnya itu. ${ }^{31}$

${ }^{28}$ Maktabah Syamilah, al-Bukhari, Jami al-shahih.

${ }^{29}$ Maktabah syamilah, Ibn Hajar, Fath al-Bārí.

${ }^{30}$ Q.S.at-Taubah (9) ayat 60.

${ }^{31}$ Anwar Prabu, Perilaku dan Budaya Organisasi. Perilaku dan Budaya Organisasi, 
Keberhasilan program-program sosial yang dilakukan majelis at-Taqwa tent unya tidak terlepas dari kinerja pemimpin majelis tersebut.

2. Hadis Mushkilyang Terkait Makanan atau Minuman

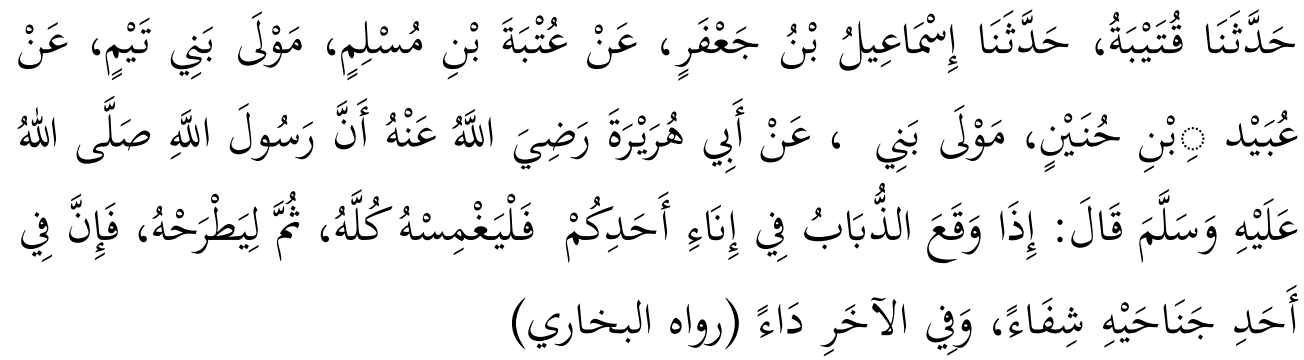

"Telah menceritakan kepada kami Qutaibah, telah menceritakan kepada kami Isma'il bin Ja'far dari 'Utbah bin Muslim pelayan Bani Taim dari 'Ubaid bin Hunain pelayan Bani Zuraiq dari Abu Hurairah ra. bahwa rasulullah saw bersabda : " Apabila seekor lalat hinggap di tempat minum salah seorang dari kalian, hendaknya ia mencelupkan ke dalam minuman tersebut, kemudian membuangnya, karena pada salah satu sayapnya terdapat penyakit dan pada sayap lainnya terdapat obat penawarnya." 32

Hadis tersebut dipahami dengan konteks sekarang dan Jamaah majelis taklim at-Taqwa sesuai dengan standar kesehatan. Mereka tidak mengerti kitab sharh yang berbahasa Arab, tetapi pemahaman mereka berangkat dari pengalaman hidup. Kehidupan yang mengajarkan mereka bahwa jika pola hidup bersih yang dijalankan maka akan mendatangkan kesehatan, sebaliknya jika menjalani pola hidup kotor maka akan mendatangkan penyakit. Ibn Hajar mengutip pendapat Abū Muḥammad al-Mālikī mengatakan bahwa lalat terlahir dari kotoran. Walaupun demikian, pada lalat terdapat manfaat, jika lalat besar dipotong kepalanya lalu badannya digosokkan dengan keras ke rambut seseorang, maka hal tersebut dapat menyembuhkan penyakit tha'lab dan mampu mengurangi rasa sakit akibat sengatan lebah. lalat selalu melindungi dirinya dengan sayap kiri, itu berarti pada sayap kanannya terkandung obat antibiotik, ${ }^{33}$ seperti bisa ular dapat menyembuhkan orang yang digigit ular.

Para Jemaah at-Taqwa belum mengetahui hasil penelitian tentang lalat yang jumlahnya sangat signifikan, berkisar kurang lebih 3.880 jenis

${ }^{32}$ Bukhāri, Jamì' al-Sahịh no 5782.

${ }^{33}$ Maktabah syamilah, Ibn Hajar, Fatḥ al-Bāri 
sebagaimana yang dikutip Susilowati dari Australian Diptera Catalog. ${ }^{34}$ Meski Hadis Nabi saw tidak menyebutkan jenis lalatnya secara spesifik, tetapi dapat diperkiraan lalat jenis apa yang biasa saja yang biasa hinggap di tempat kotor, di antaranya adalah: pertama, lalat kerdil yang suka hingap pada bangkai, kedua, lalat hitam dan lalat kuda gemar mengisap darah, ketiga, lalat rumah senang di tempat yang kotor berperan sebagai hama dan vector/virus penyakit bahkan penyakit mematikan seperti demam tifoid, disentri, kolera, frambusia, anthrak, kusta dan TBC. Lebih jauh Poedji Hastutiek dan Loeki Enggar Fitri menyebutkan bahwa lalat rumah atau musca domestica sebagai salah satu spesies serangga terbanyak yang ada di seluruh dunia. Lalat rumah dikategorikan sebagai pengganggu, vector mekanis beberapa penyakit dan penyebab myiasis pada manusia dan hewan. Pengganggu dari kebersihan dan ketenangan suatu lingkungan. ${ }^{35}$

Setyautami memaparkan lalat musca domestica termasuk vector mekanis dari shigella sp yang menyebabkan diare. Lalat musca domestica juga ternyata banyak terdapat di pasar tempat penjualan ikan, daging dan tempat sampah yang isinya membusuk. ${ }^{36}$ Yunita Panca Putri menegaskan bahwa beberapa penyakit tersebut ditularkan lalat melewati makanan atau minuman. Bibit penyakit dibawa lalat melalui anggota tubuhnya seperti mulut, sayap, badan dan rambut-rambut pada kaki. ${ }^{37}$

Walaupun jemaa majelis taklim at-Taqwa tidak mengetahui secara rinci tentang lalat, tetapi mereka paham bahwa makhluk ini membawa racun, mereka mengetahui jika makanan atau minuman yang dihinggapi lalat maka harus dibuang karena dikhawatirkan tertular racun yang dihinggapi lalat tersebut. Pemahaman pengurus majelis taklim at-Taqwa tentang isi hadis tersebut bisa dipengaruhi oleh psikologi organisasi pada tema kepuasan kerja/ job satisfaction. Hal ini dibuktikan ketika acara khataman dan makan bersama, konsumsi yang dihidangkan berasal dari hasil memasak beberapa orang jamaah, tidak dibeli dari luar Jema'ah yang kebersihannya masih diragukan. Apa yang dilakukan Jamaah MT atTaqwa tersbut termasuk kepada aspek fisik kerja, psikologis kerja dan

\footnotetext{
${ }^{34}$ Susilowati,http;//repository.unimus.ac.id, diunduh tanggal 22 Juni 2020.

${ }^{35}$ Poedji Hastutiek dan Loeki Enggar Fitri, "Potensi Musca domesticalinn Sebagai Vektor Beberapa Penyakit”, https://jkb.ub.ac.id, diunduh 22 Juni 2020.

36 Annisa Setyautami, "Perbandingan Jumlah Lalat Rumah (Musca Domestica) Yang Bagian Luar Tubuhnya Dilekati Bakteri Shigella SP di Pasar Gadang dan Pasar Madyopuro Malang” Eprint.umm.ac.id, diunduh tanggal 22 Juni 2020.

37 Yunita Panca Putri, "Keanekaragaman Species Lalat (diptera) dan Bakteri pada Tubuh Lalat di Tempat Pembuangan Akhir Sampah (TPA) dan Pasar", Jurnaldampak.ft.unand.ac.id, diunduh 22 Juni 2020.
} 
peraturan kerja. Mengola makanan sendiri lebih memuaskan dan lebih hemat dibandingkan dengan membeli di luar. ${ }^{38}$

3. Hadis Mushkilyang Berhubungan dengan Pengobatan

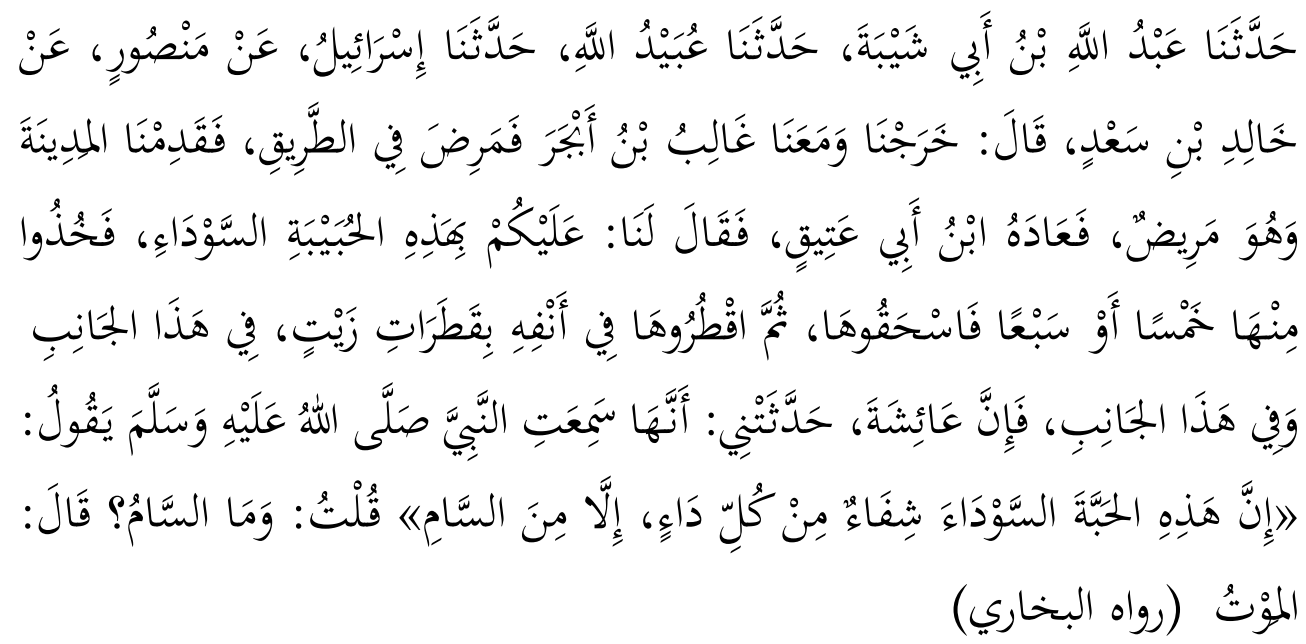

"Telah menceritakan kepada kami Abdullah bin Abu Syaibah telah menceritakan kepada kami Ubaidullah telah menceritakan kepada kami Israil dari Manshur dari Khalid bin Sa'd dia berkata; Kami pernah bepergian dan bersama kami Ghalib bin Abjar, di tengah jalan ia jatuh sakit, ketika sampai di Madinah ia masih menderita sakit, lalu Ibnu Abu 'Atiq menjenguknya dan berkata kepada kami; "Hendaknya kalian memberinya habbat al-sadā" (jintan hitam), ambillah lima atau tujuh biji, lalu tumbuklah hingga halus, setelah itu teteskanlah di hidungnya disertai dengan tetesan minyak sebelah sini dan sebelah sini, karena sesungguhnya Aisyah ra. pernah menceritakan kepadaku bahwa dia mendengar nabi saw bersabda: "Sesungguhnya habbat al-sadā" ini adalah obat dari segala macam penyakit kecuali as-Sām." Aku bertanya; "Apakah sam itu?" beliau menjawab: "Kematian."139

Jamaah at-Taqwa memahami hadis tersebut sebagai landasan dari pengobatan herbal, seperti yang dijelaskan Ibn Hajar ${ }^{40}$ bahwa hadis ini merupakan sesuatu yang diisyaratkan Ibn 'A $\mathrm{A}$ tiq sebagai hadis yang tentang pengobatan. Para ahli pengobatan mengatakan bahwa Habbät al-Sawdā adalah obat penyakit pilek yang disertai bersin. Jemaah majelis taklim at-

${ }^{38}$ Anwar Prabu, Perilaku dan Budaya Organisasi. Perilaku dan Budaya Organisasi, 105-107

${ }^{39}$ Bukhāri, Sahịh Bukhārì, no 5687

${ }^{40}$ Maktabah, Ibn Hajar, Fath al-Bāri 
Taqwa tidak mengetahui bahwa Habbāt al-Sawdā'‘ adalah tanaman sejenis rumput yang hidup di daerah Mediteranian seprti Kuwait, India, Saudi Arabia, Mesir dan lain-lain. Tetapi mereka sudah paham di Indonesia pun banyak tumbuhan yang dapat dijadikan obat. Indonesia sebagai negara yang beriklim tropis tentu memiliki kelebihan di mana hampir semua tanaman bisa tumbuh dan berkembang tetapi masing-masing mempunyai khasiat tersendiri. Menurut Suci dan Asmawati, Indonesia menduduki rangking kedua setelah Brazil sebagai negara yang memiliki tumbuhan obat-obatan, yaitu sekitar 35.000. yang sudah diidentifikasi baru hanya 1000 dan 300 jenis tumbuhan telah digunakan untuk obat. ${ }^{41}$

Syamsul Hidayat dan Rodame menjelaskan baru 269 tumbuhan yang berkhasiat untuk mengobati berbagai macam penyakit baik yang ringan maupun yang berat. contohnya tumbuhan adas yang buahnya bisa dimanfaatkan untuk mengobati penyakit batuk, sakit perut, sariawan, memperlancar dan memperbanyak ASI, meringankan nyeri haid, perut kembung, mual, diare, sakit kuning, kurang nafsu makan, asma, hernia, insomnia, batu ginjal, rematik dan memperbaiki penglihatan. ${ }^{42}$ Yusuf Wibisono dan Zikri Azham menambahkan tumbuhan yang dapat dijadikan obat di antaranya yang mengandung NPJ terbesar yaitu jenis clidemia hirta, ligodium circinatum dan fordia splendidissima. ${ }^{43}$

Habbät al-Sawdā' atau Nigella sativa L. sendiri tumbuhan obat aromatic yang mengandung natrium, kalsium, kalium dan zat lain yang memiliki sumbangan terhadap kesehatan. ${ }^{44}$ Jemaah MT. at-Taqwa memahami tumbuhan tersebut dapat dijadikan obat-obatan yang mengandung vitamin, protein, kalsium, asam amino, minyak atsiri, natrium, asam limonelat dan saponin. Pemahaman ini terjadi karena adanya motivasi karyawan/emfloyee motivation yang ada dalam dirinya atau disebut sebagai motivasi intrinsik. Bisa juga faktor dari orang lain yang dinamakan motivasi ekstrinsik. Kedua hal tersebut terjadi di majelis taklim at-Taqwa, pengurus dan jamaah terkadang melakukan sesuatu yang karena dorogan ingin menjadi pribadi yang baik dan dapat bermanfaat bagi orang banyak. Pada sisi lain terkadang semangat membantu teman atau orang lain karena timbul karena keinginan untuk mendapatkan ridha Allah Swt, dan masuk ke Syurga-Nya.

41 Suci Cahaya dan Asmawati,"Inventarisasi Tumbuhan Berkhasiat Obat Bagi Masyarakat Kelurahan Lapuko Kecamatan Moramo Kabupaten Konawe Selatan”, ojs.uho.ac.id, diunduh tanggal 22 Juni 2020.

${ }^{42}$ Syamsul Hidayat dan Rodame, itab Tumbuhan Obat (Jakarta:AgriFlo,2015)

43 Yusuf Wibisono dan Zikri Azham, "Inventarisasi Jenis Tumbuhan yang Berkhasiat Sebagai Obat", https://media.neliti.com, diunduh tanggal 10 Desember 2019)

44 Firdaus Anwar, "Sepuluh Manfaat Habbatussauda Untuk Kesehatan", https://m.detik.com, diunduh 10 Desember 2019) 
4. Hadis Mushkil Bertema Politik tentang Kepemimpinan Seorang Perempuan

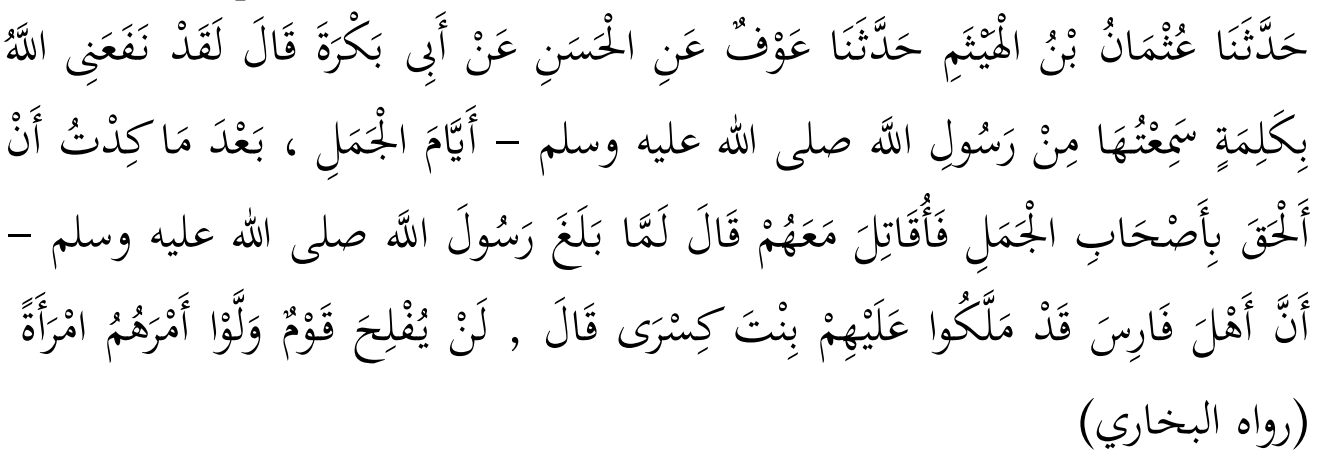

"Telah bercerita kepada kami Utsman bin Haitham telah bercerita kepada kami Auf dari Hasan dari Abi Bakrah berkata: Allah swt memberikan manfaat kepadaku dengan sebuah kalimat yang aku dengar dari rasulullah saw pada hari perang jamal, setelah aku hampir membenarkan mereka (Ashabul Jamal) dan berperang bersama mereka, ketika sampai kabar kepada rasulullah saw bahwa bangsa Persia mengangkat putri Kisra sebagai pemimpin, beliau bersabda: Tidak akan beruntung suatu kaum yang menyerahkan urusan (pemerintahan) mereka kepada seorang wanita." 45

Hadis mengenai kepemimpinan dari kalangan perempuan dipahami Jemaah majelis taklim at-Taqwa sebagai bentuk persamaan hak antara laki-laki dan perempuan. Menurut mereka, wanita mempunyai kesempatan yang sama dengan laki-laki, terbukti pada masa Rasulullah Saw., perempuan mempunyai kesempatan untuk bekerja di ranah publik, ikut membantu dan berkontribusi dalam memperjuangkan Islam. Hal ini menunjukan bahwa kemampuan perempuan dianggap sama dengan lakilaki, walaupun tetap saja terdapat batasan-batasn tertentu, dan tidak menyalahi kodratnya sebagai perempuan. Pendapat mereka senada dengan al-Tabari yang dikutip Ibn Hajar yang memperbolehkan wanita menjadi hakim dan saksi. ${ }^{46}$ Berbeda dengan al-Khattabi dan jumhur yang menjelaskan bahwa perempuan tidak boleh menjadi pemimpin negara, qāọil hakim, dan tidak boleh jadi wali akad bagi putrinya. ${ }^{47}$

Kenyataan di lapangan ditemukan bahwa jemaah at-Taqwa belum pernah mendengar penjelasan Ibn Hajar mengenai hadis dengan menggunakan pendekatan sejarah tersebut. Hadis ini muncul karena raja

45 Bukhari, Jamì' al-Sahịh hadis no 4425.

${ }^{46}$ Maktabah Syamilah, Ibn Hejar al-Asqalānì, Fath al-Bārī, 149-150

${ }^{47}$ Maktabah Syamilah, Ibn Ḥajar al-Asqalānì, Fatḥ al-Bārí, 150 
Kisra dahulu merobek-robek surat Nabi Saw. yang berisi ajakan menyembah kepada Allah Swt. lalu Rasulullah Saw. berdoa agar kerajaan Persia hilang dan hancur. Allah swt mengabulkan permintaan utusan-Nya dengan jalan raja Kisra dan anak laki-lakinya saling membunuh dan tinggallah cucu perempuannya yang bernama Buwaran binti Shirawaihi bin Kisra bin Barwiza sebagai raja. ${ }^{48}$

Pemahaman jemaah at-Taqwa tentang kepemimpinan perempuan jika ditinjau dengan pendekatan psikologi organisasi termasuk dalam ruang kepemimpinan organizational change dan grouf prosses within an organization. Seorang pemimpin harus mampu membangkitkan loyalitas, mengedukasi, memberikan motivasi dan keteladanan bagi anggotanya. ${ }^{49}$

Selain itu, seorang pemimpin harus mampu memposisikan dirinya sebagai orang yang berpengaruh di mata anggotanya, sehingga mampu membawa organisasi yang dipimpinnya menuju gerbang kesuksesan. Hal itu bukan hanya bisa dilakukan oleh laki-laki saja, tetapi perempuan pun mampu. Sebagaimana majelis taklim at-Taqwa yang notabene sebagai majelis taklim ibu-ibu, pun dipimpin oleh seorang perempuan.

Lahirnya kepecayaan dari para anggota disebabkan oleh karakter kepribadian yang sangat kuat yang dimiliki oleh pemimpin oraganisasi tersbut. Selain itu ia juga harus selalu menjunjung tinggi etika, dan integritas. ${ }^{50}$ Bukan hanya dari faktor pemimpin saja, kemajuan sebuah orgaisasi juga harus ditunjang oleh usaha para anggota.

Banyaknya program-program majelis taklim di bidang agama dan sosial yang berhasil dilaksanakan, tentu tidak terlepas dari kemampuan pemimpin majelis taklim tersebut dalam memberikan perubahan positif di oeganisasinya, dan juga dapat memberikan teladan sehingga memberikan energi terendiri bagi para anggotanya dalam melakukan kegiatan-kegiatan majelis taklim.

\section{SIMPULAN}

Hasil kajian terhadap resepsi jemaah majelis taklim at-Taqwa tentang hadis-hadis Mushkilyang terkait akidah, makanan/minuman yang dihinggapi lalat, pengobatan dari habbat al-sawdā' dan pemimpin perempuan. Keempat hadis tesbut dipahami secara kontekstual. Mereka memahami hadis tentang matahari yang bersujud kepada Allah merupakan perintah kepada manusia agar selalu taat kepada perintah Allah. Hadis makanan yang dihinggapi lalat

${ }^{48}$ Maktabah Syamilah, Ibn Ḥajar al-Asqalānī, Fatḥ al-Bārī, 151

49 Artikel DJKN, "Pemimpin dan Kepemimpinan Kita", s://www.djkn.kemenkeu.go.id, diunduh tanggal 22 Juni 2020.

${ }^{50}$ Avin Helmi dan Iman Arisudana, "Kepemimpinan Transformasional, Kepercayaan dan Berbagi Pengetahuan Dalam Organisasi", https://jurnal.ugm.ac.id, diunduh tanggal 22 Juni 2020. 
berdasarkan ilmu kesehatan bahwa lalat membawa racun dan makanan yang dihinggapinya harus dibuang supaya tidak sakit. Hadis pengobatan dari habbāt al-sawdā' dipahami sebagai inspirasi pengobatan herbal. Hadis pemimpin dari golongan perempuan dipahami sebagai motivasi dan kesetaraan gender bahwa perempuan harus terampil dan propesional dalam keilmuan politik seperti juga kaum adam. Permasalahan-permasalahn yang terdapat pada keempat hadis tersebut kemudian memberikan implikasi pada jemaah sehingga menambah kepedulian sosial, menjadi motivasi untuk selalu berbuat baik, meberikan perubahan organisasi dan proses grouf yang terjadi pada majelis taklim at-Taqwa.

\section{DAFTAR PUSTAKA}

A'zamī, M.M. Hadis Nabawi dan Sejarah Kodifikasinya. Jakarta: Pustaka Firdaus,2000.

Ali, Nizar. Hadis Versus Sains Memahami Hadis-hadis Mushkil. Yogyakarta: Teras, 2008.

Ardianto, Elvinaro dan Siti Karlinah. Komunikasi Massa. Bandung Sembiosa Rekatama Media, 2012.

Bustaman, Hana Djumhana. Integrasi Psikologi dalam Islam: Menuju Psikologi Islami. Yogyakarta: Pustaka Pelajar, 1997.

Ekawarna. Manajemen Konplik dan Stress. Jakarta: Bumi Aksara, 2018. Etzioni, Amitai. Organisasi-organisasi Modern. Depok: UI Press, 1985.

Hidayat, Syamsu dan Rodame. Kitab Tumbuhan Obat. Jakarta: AgriFlo, 2015.

Al-Khuli, Hilmi. Menyingkap Rahasia Gerakan-Gerakan Sholat. Yogjakarta: Diva Press, 2012.

Muslim. Sahihh Muslim. Bandung: Dahlan, t.th.

Mustaqim, Abdul. Ilmu Ma'anil Hadis Paradigma Interkoneksi. Yogyakarta: Idea Press, 2016.

Mulyana, Deddy. Nuansa-nuansa Komunikasi. Bandung: Rosda Karya, 2005.

Prabu, Anwar. Perilaku dan Budaya Organisasi. Bandung: Refika Aditama, 2010.

Qutaibah, Ibn. Rasionalitas Nabi Saw. Jakarta: alGhuraba, 2008.

Sashkin, Marshall dan Sashkin, Molly. Prinsip-prinsip Kepemimpinan. Jakarta: Penerbit Erlangga, 2011.

Sears, David. Jonathan dan Peplau, Anne. Psikologi Sosial. Jakarta: Penerbit Erlangga, t.th.

Shalaby, Ahmad. Kehidupan Sosial Dalam Pemikiran Islam. Bandung: Amzah, 2001.

Sumaatmaja, Nursid. Manusia Dalam Konteks Sosial, Budaya dan Lingkungan Hidup. Bandung: Alfabeta, 2003. 
Tagala, Mustadin. Psikologi Industri dan Organisasi. Depok:RajaGrafindo Persada, 2018.

Al-Tirmìihi. Sunan al-Tirmìdhì. Beirut: Dar al-Fikr, 2009.

Wawancara dengan ibu $\mathrm{Hj}$ Iis Mulyadi (ketua MT. at-Taqwa), Hj Upi (sekretaris MT. at-Taqwa) dan ibu Hj. Sriyatin, APP, S.Kep, M.Kes. (bidang pendidikan)

Wirawan. Kepemimpinan. Jakarta: RajaGrafindo Persada, 2013. 